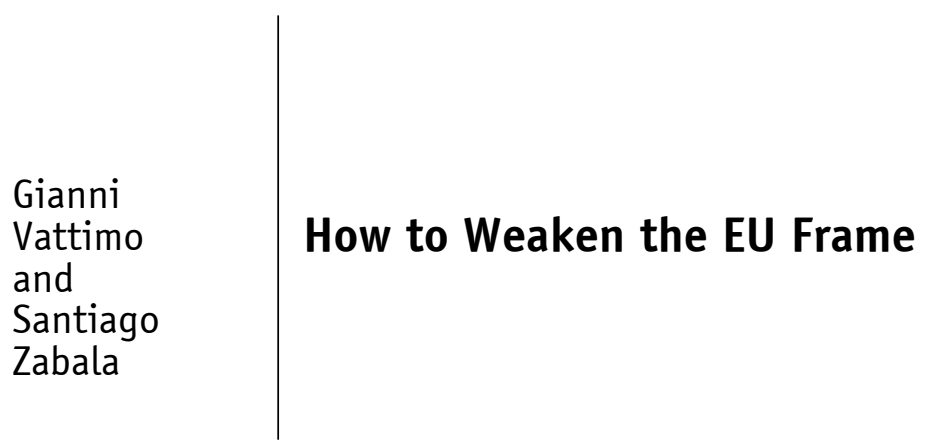

Gianni Vattimo is emeritus professor of philosophy at the University of Turin and a former member of the European Parliament. His most recent books include Della Realtà (2012) The Responsibility of the Philosopher (2010), A Farewell to Truth (2011), and Hermeneutic Communism (2011, coauthored with $S$. Zabala), all translated into several languages.

Santiago Zabala is ICREA Research Professor of Philosophy at the Pompeu Fabra University. His books include The Hermeneutic Nature of Analytic Philosophy (2008), The Remains of Being (2009), and, most recently, Hermeneutic Communism (2011, coauthored with G. Vattimo), all published by Columbia University Press. His forthcoming book is Only Art Can Save Us: The Emergency of Aesthetics.

\section{How to Weaken the EU Frame}

\section{Abstract}

Even though the European Union was created to avoid new wars within the continent and promote social integration, it has never questioned its political horizon. This is why legal scholars are continuously reminding us that until our constitution is ratified, the
Union will continue to lack the political debate that is at the center of any mature democracy. But if the Union has now reached a new record of unpopularity it is because of this general neutering of politics, which allows technocrats to prevail over politicians and indifference over democracy. The logic behind our thesis is not that countries cannot leave the Union but that doing so would create more harm than staying. However, this does not imply there is no alternative; quite the contrary, a profound resistance to the Union has not only been discussed but also practiced throughout Europe.

Europe will one day be a single bureau, and those who 'work together' will be the employees of their own bureaucracy.

Martin Heidegger, 1942

Although these words from one of the most important philosophers of the $20^{\text {th }}$ century sound prophetic today, they must be interpreted together with the concerns of different contemporary intellectuals over the subordination of society to technological measures. As the American economist Paul Krugman pointed out in a New York Times Magazine article when the global financial crisis began, the problem with establishment 
economists was that they mistake mathematics for truth; they were "seduced by the vision of a perfect, frictionless market system [and] need to abandon the neat but wrong solution of assuming that everyone is rational and markets work perfectly." ${ }^{1}$ The idea that scientists can solve or reform political, economic and social matters sits at the origin of both the European Union's current austerity measures and its cultural crisis. The right wing populist parties' success throughout Europe in 2014 elections must be read in this light. Science is not enough. We need more politics, exchange, and interpretation.

Even though the Union was created to avoid new wars within the continent and promote social integration, it has never questioned its political horizon. This is why legal scholars are continuously reminding us that until our constitution is ratified, the Union will continue to lack the political debate that is at the center of any mature democracy. As we all know, these debates have been substituted by technical and bureaucratic agreements in order to allow the Union to function correctly. But if the Union has now reached a new record of unpopularity (as a recent study by the Pew Research Institute demonstrated $)^{2}$ it is because of this general neutering of politics, which allows technocrats to prevail over politicians and indifference over democracy.

1 Paul Krugman, "How Did Economists Get it So Wrong?," The New York Times, September 02, 2009, Accesed October 28, 2014, Http://Www.Nytimes.Com/2009/o9/06/ Magazine/o6economic-T.Html?Ref=Paulkrugman\&_R=0.

2 "The New Sick Man of Europe: The European Union," in Global Attitudes Project, (Washington, D.C.: Pew Research Center, May 13, 2013), accessed October 28, 2014, http://www. pewglobal.org/2013/05/13/the-new-sick-man-of-europe-theeuropean-union/.
There is one thing most European philosophers agree upon today: the difficulty the various member countries would have trying to leave the Union. This is probably why thinkers as different as Jürgen Habermas, Chantal Mouffe, and Slavoj Žižek have recently encouraged internal transformations: Habermas calls for a "democratization of the Council," 3 Mouffe for a "debureaucratization of its political environment," 4 and Žižek for a "socialization of its banks." While we agree with our colleagues' suggestions, we can't help wondering whether these are not other ways to emphasize how Europe has become framed within the Union. The logic behind our thesis is not that countries cannot leave the Union but that doing so would create more harm than staying. However, this does not imply there is no alternative; quite the contrary, a profound resistance to the Union has not only been discussed but also practiced throughout Europe. These resistances are not meant to put an end to our ties with the Union, but to weaken them, that is, to create greater democratic participation in vital social matters. This is why the rise of the Five Star Movement in Italy and Podemos in Spain are going to be an important opportunity to weaken the ongoing industrial and economic policies we've been submitted

3 Jürgen Habermas, In Bernd Riegert, "A Philosophical Critique of EU Politics,” Deutsche Welle, April 27, 2013.

4 Chantal Mouffe, "Five Minutes with Chantal Mouffe: 'Most countries in Europe are in a post-political situation," The London School of Economics Blog: September, 16 2013, accessed October 28, 2014, http://blogs.lse.ac.uk/ europpblog/2013/o9/16/five-minutes-with-chantal-mouffemost-countries-in-europe-are-in-a-post-political-situation/.

$5 \quad$ Slavoj Žižek, "The Cyprus Crisis is A Symptom of What is Rotten in the Eu," The Guardian, April, 8, 2013, Accessed October 28, 2014, Http://Www.Theguardian.Com/ Commentisfree/2013/Apr/o8/Cyprus-Crisis-SymptomRotten-Eu 
to. Together with Alexis Tsipras, they are our change to request a profound social change within the Union's policy.

As we can see, if we are framed within the Union it's not because its technicians remained neutral, but rather because they have chosen sides, as the many neoliberal infrastructure projects and economic measures imposed upon member states demonstrate. While in Italy the government is asked to move on with the construction of a high-speed railway line (TAV), which will link Turin and Lyon regardless of its environmental impact and popular opposition, in Spain, Mariano Rajoy has began to privatize a number of hospitals and health centers, blocking hundreds of thousands of people from access to medical treatments. These two measures are an indication not only of the Union's indifference when it comes to political decisions but also of its persisting interest in framing Europe financially and physically. But what lies behind these measures? According to a recent study by the Transnational Institute these (and many other) measures are meant to privatize public infrastructures and services as a condition for loans. We don't think these measures should be opposed only because of the devastating effects they had on developing countries in the 1980s and 1990s (when the International Monetary Fund and World Bank called the shots) but also because of the cultural implications. The economic domination of the European Central Bank over these past ten years has affected us at a financial level, but also culturally. In order to promote competition and become more effective, we also had to become less human.

As we can see, the cultural problem of Europe does not lie in the education of its citizens, but in their social sensibility, which the Union is trying to undermine through the privatization of public infrastructures and social services. However, these same measures have given birth to powerful protest and resistance movements, such as NO-TAV and the "white tide" movement, and these have become spaces for solidarity among concerned citizens. Although the Italian and Spanish governments have begun to take violent measures against these movements as the recent reform of the Spanish penal code (against unauthorized protest) or the militarization of the Val di Susa (where the TAV is supposed to cross), we must support and join these protesters in order to weaken our ties with the Union.

Communism, Lenin once said, was "Soviet power plus the electrification of the whole country"; Europe today is "electrification without soviets." The communities of Europe have technological programs but are without power. This power can be restored only when political life prevails once again over the technocrats. This life can be restored through those weak, but visible deputes, that today are represented in the Parliament. 